\title{
Effect of behavioural finance of investor's participation on investments in capital markets of Bank of Kigali staff, Rwanda.
}

\author{
Marie Louise TUYISHIME $^{1}$ and Dr. Claude RUSIBANA ${ }^{2}$
}

\author{
${ }^{1}$ School of Business and Economic, Mount Kenya University, \\ Kigali, Rwanda
}

${ }^{2}$ School of Accounting and Finance, University of Kigali, Rwanda

\begin{abstract}
The capital market offers a multitude and alternative investments products with high expected returns and low risk comparatively to others investments. But it is not fully understood by why people are not interested a lot in investing in capital market; particularly the staff from the institutions involved in capital market through selling and buying are among non-interested. This study assessed the investor's participation and dividend returns on investments in capital markets a case of bank of Kigali staff, Rwanda. Specific objectivewas to examine the effect of behaviour finance of investor's participation on investments in capital markets of bank of Kigali staff; Rwanda. The significance of this study was to generate information about the investor's participation and dividend returns on investments in capital markets and the study had a great impact to different parties involved in capital market, investors, GoR, institutions. The study was compared rational and irrational theories of investing in Capital Market and was focused on behavioural finance theories. The researcher used a descriptive and analytical research design based on quantitative data. The target population was 1282 employees of bank of Kigali staff and using the Slovin's formula, the sample size of 92 employees sampled in target population located at Kigali city branches. The 92 respondents from target population of all staff have been stratified according the division of staff for four branches located at Kigali city; and interviewed through questionnaires. During research analysis process, the SPSS vision 20 has been used and correlation and regression has been used. The results were presented by using tables, while frequencies and percentages have been used to analyse and interpret the collected data. The study also found that there is a strong effect of behaviour finance factors of investor's participation on investments in
\end{abstract}

capital markets $93.5 \%$ of respondents confirmed that there is a strong impact of availability of funds for investors, $96.7 \%$ confirmed that the amount of return pushes the respondents to invest in capital market. The knowledge level of investments was positively correlated with behavior finance with correlation coefficient of 0.82 , this leads to confirm that there is significant relationship between knowledge level of investments and behavior finance. This research recommends institutions involved in capital market and other financial institutions to speed up the campaign to mobilize their employees to invest in different products of capital market.

\section{Introduction}

The stability of macroeconomic finance is considered as the pillar of a financial system of the country for providing the long-term finance that is sustainable and affordable (Cassimon,et al., 2016). In global era, buy and sell long-term debt or stocks (equity) are very important for mobilizing the investments funds and are the main characteristics of capital market. The capital market is very important to ensure the long-term financing of strategic sectors, and the realisation of risk management tools for the financial sector, participants and towards end users (Cassimon,et al., 2016). The capital market supports the national economy of a country through its contribution to the national gross domestic product and as a source of company's fund (Lindawati and Roselin, 2013). In order to achieve the Goals for the Sustainable Development by the end of 2030, the developing countries need approximately \$4trillion annual investment (World Bank, 2019).

The Africa We Want (AGENDA 2063) recommended that the mobilization of domestic resource will contribute $75 \%$ to $90 \%$ country in order to finance the Agenda 2063 and the capital markets is among the mobilisation resource (African Union 
Commission, 2015). Through, Africa Agenda 2063, Africa annual rate of GDP must growth at least $7 \%$ the strategy of putting in place policies for increasing the savings and investment rates are set up for achieving the targets. This needs a lot of investment in terms of human and financial capital (African Union Commission 2015). The economy of Rwanda is relying on services and agriculture with their contribution being $47 \%$ and $31 \%$ respectively during the fiscal year 2017-2018 (MINECOFIN, 2018). From the macro economy perspective, the country is doing a lot to increase the GDP. For thus, Rwanda has established strong progress policies such as macroeconomic, fiscal and monetary policies. It is in this order that Government of Rwanda (GoR) established Capital Market in March 2007 and officially launched in 2008 with the purpose to guide the initiation and development of financial sector industry in Rwanda.

Actually, Rwanda's Capital Market Authority (CMA) is operating and coordinating all activities in relation to capital market in the country. It was created to improve the Country's Economy by sustaining high economic growth through easy access to long term finance (capital): supplements banking sector, promoting the development of financial sector services, tapping into savings from diaspora community looking to invest in their native country, to attract foreign direct investments (FDI's), and encourage country's self-reliance (Euro Bond, Government Treasury Bonds, ...).

In its National Strategy for Transformation (NST1) for 2017-2024, the government of Rwanda has made capital market one of the priorities. Through 7 Years Government Programme: (NST 1), the government of Rwanda was committed to follow the ten-year master plan of the capital market in Rwanda, for the development and the increase of its dynamism. This will be achieved through the identification, attraction and exploitation of new sources in finance such as municipal bonds, crowd funding, green bonds, venture capital funds among others (GoR, 2016).

Rwanda's Capital Market Authority (CMA) has a strong plan to mobilize investors such individual and company, national and foreign. Today people special Rwandese does not understand the role of the capital market and its functionalities. Therefore, most investors prefer to invest their money outside of the capital market through savings, deposits and housing which are no better investments solutions than the capital market. Hussain (2012) demonstrated that the average return obtained after investing in shares reached more than $15 \%$ per year but it was not attractive to the investor.

\section{Review of Literature}

\subsection{Investor's participation and dividend returns Investor's participation}

Investors generally interact with their neighbors, relatives and family members, colleagues and friends to exchange information and discuss stocks. Therefore, the investments decision making can be conceptualized as a complex behavior that is influenced by rational and irrational factors that contribute to inefficiency security markets. The influence of social factors such as social interactions, the media and the internet explain the process of decision- making for investors. Information is one of the economic factors that can affect the value of a business or an investment.

Socio- economic factors include what you keep in mind after manipulating and calculating the expected present and future value of an investment portfolio or any kind of business factors that may affect the value of a company or business investment. Some of the socio-economic factors that influence the investors in making decision to invest in capital markets are:

Warne (2012) explain that the fluctuation of prices impacts the investment model of individual investors because most people are conscious of stock market transactions. In his research, Shafi (2014) stated that information on stock market fluctuations, press coverage, internet information, the movements of recent information and price on government holders are important for investors of recent price and information on government holders are important for investors.

The uncertainty of the investment as to whether it will provide a profit, or a loss is named risk. Each investor encounters the risks depending on the objectives of the investment (Rice, 2014). As described by Shafi (2014), the risk capacity is considered as safety parameters, return and risk average, liquidity and capital appreciation. The investors have different capacity to stand risks and therefore have different types or ways of investments. They are therefore requested to do financial planning depending on their needs. Brahmabahatet al. (2012) reported that risk tolerance reduces with increasing age of investors. The aggressive investors who are ready to accept losing the capital in question of higher returns are named risk-tolerant investors.

According to Injodey and Alex (2011), investors who want to make a higher return will invest in higher risk securities. In contrast, investors who avoid risk will invest in lower risk securities, resulting in low resulting in low returns. Nosic and Weber (2007) stated three important determinants of 
risk taking behaviour such as risk attitude, beliefs and perceptions of risk.

The main purpose of investor is to make profit. They can to invest in highly risky securities because they have confidence in that high risk can give high return, the level of annual earnings and savings is influence investor decision making (Warne, 2012).

Among factors influencing the decision making there is also psychological factors that refer to the feelings, thoughts and other cognitive characteristics that influence a person's behaviour, mind functions and attitude and they have an influence on human thinking. Among psychological factors there are:

The motivation refers to what drives, or moves, an individual to take a certain action. In other words, motivation describes what kind of objectives an individual aims to reach through an action (Beck, 2000; Ryan and Deci, 2000). Different individuals can have different motivations for the same action, driven by differing goals and attitudes.

According to Ryan and Deci (2000), the individual's actions can be intrinsically or extrinsically motivated. Vansteenkisteet al., (2010) stated that intrinsically motivated actions are performed for the inherent satisfaction that they cause; in contrast extrinsically motivated actions have instrumental value: they are taken in order to reach a separable outcome.

Overconfidence refers to a person who has more confidence in his/her ability in considered situation (Tapia and Yermo, 2007). Odean (1998) indicated that overconfident investors have in their mind that they can pick stocks better than others. They think that they know the appropriate time for investing and entering and existing the market. However, their returns are lower than those of other investors. On other hand, Kyle and Wang (1997) stated that overconfident investors may more returns or profits than rational investors make more returns or profits than other rational investors; because the transactions volume also increased because of them. Pulford and Colman (1997) showed that because of working under a lot of social pressures; men are more confident than women.

Optimism indicates the hope that everything will be better, and it comes from overconfidence. For example, investors have the feeling and think that the market will be better and go high in the future. Gervais et al., (2002) have demonstrated that optimistic behaviour is good for the market because is the key driving point for investors to invest as when the investors feel positive about the decisions made. Kahneman and Riepi (1998) mentioned that optimism which is unnecessary can lead people to misjudge changes that occur due to certain difficult situations in their life.

Every person is afraid of losing and particularly the investors don't want to lose any part of their investments. Kabraet al., (2010) showed that while there are opportunities for market progress or valid initial public offerings, some investors even capitalise their investment based on the risk they can be able to manage.

Investors disclose and make discussion on their business and investments with relatives and closed in order to decide accordingly. Bikhchandani and Sharma (2000) reported that some investors may have an influence on the decision of other investors. On the other hand, Obenberger (1994) specified that investors don't consider the recommendation from the analyst, family members, or other advices from different experts in the field or sector.

\subsection{Behavioural finance of investor's participation}

Gill et al. (2018) in their research, they reported that there was a significant positive relationship between returns and decision making on individual investor behaviour. They showed that $33.2 \%$ change in the decision- making behaviour is attributed to economic expectations or returns. Besides, the overconfidence bias influenced significantly and had a positive relationship with the decision making as investor behaviour on the investment. The authors showed also that, $66.8 \%$ of decision making behaviour was attributed to different other factors.

In Kenya, Ngahu (2017) showed that stock affordability $(\mathrm{B}=0.327, \mathrm{p}<0.007)$ and third parties' opinion $(\mathrm{B}=0.327, \mathrm{p}=0.042)$ influenced significantly and had positive effect in decisions making among the retail investors. It also emerged that information $(\mathrm{B}=0 .-.070 ; \mathrm{p}<0.395)$ had $\mathrm{a}$ negative but insignificant role on retail investments' decisions while herding behaviour $(\mathrm{B}=0.043, \mathrm{p}=$ 0.702 ) had a positive but insignificant role towards decisions among retail investors at the NSE.

Mahina, et al. (2014) showed that the average men of 4.05 as economic factors, average mean of 3.96 as psychological factors, an average mean of 3.64 as social factors and an average mean of 3.08 as demographic factors influenced significantly and they were the major determinants of investment decisions making in the Rwanda Stock Exchange. They showed that there was a positive and linear relationship between different psychological factors (over-optimism bias, loss aversion bias, selfattribution bias, confirmatory bias) and the decision for investing in Rwanda stock market. They concluded that behavioural biases were the main suffering of the majority of investors in stock markets.

Jain and Mandot (2012) studied the effect of demographic factors on decision making in Investment in Rajasthan. He showed that different 
demographic factors such as sex $(92 \%$ male and $8 \%$ female), age (Below 25 years: $2 \%, 25-40$ years: $75 \%$, age of $40-55$ years: $22 \%$ ) and marital status, city, salary level, advertise information, occupations and capabilities majorly affect investment decision of investors.

Fares and Khamis (2011), by using the multiple regression technique studied the behaviour of individual investors in stock trading at the Amman Stock Exchange, Jordan. They found that only 4 variables were found statistically significant among 15 variables. Age, internet and broker and education level were found to be significantly influencing factors. They identified four behavioural factors such as age, education, accessibility to the internet and interaction between the investor and his/her broker that pushed the investor behaviour in decision making. In contrast, the interaction between the investor and his/her broker, had significantly and negative effects on the decision making of investors. Masomi and Ghayekloo (2011) indicated that the heuristic theory is explained by the behaviour of over $76 \%$ of the respondents. $69 \%$ of the respondents showed the overconfidence as a motivation factor. In addition, over $90 \%$ of the respondents reported that price change of stocks could have a moderate to high influence on the investment decision and behaviour of investors.

In Nigeria, the investigation by Aregbeyen and Mbadiugha (2011) found ten most impacting factors on decision making of investors. Those are inspiration by individuals who have achieved financial security trough share investment, future financial security, suggestions by trustworthy and confided in stock representatives, supervisory crew of the organization, familiarity with the possibilities of putting resources into shares, creation of the top managerial staff of organizations, late budgetary execution of the organization, possession structure of the organization, respectable expectations of future addition in share worth and extra instalments. The social variables, organization major shareholders character profile affected about $52 \%$ of the respondent in their decision making. For example, dominant parts $(71.5 \%)$ of the respondents were male vs $28.5 \%$ of female. For the marital status, about $42 \%$ respondents are single while about $57 \%$ are married. The separated/divorced from respondents make $1.6 \%$ of the total respondents.

\subsection{Behavioural Finance Theory}

The theory of behavioral finance is applicable in social science especially psychology and sociology. The theory is applied to understand deeply the economic decisions made by consumers, borrowers, investors. Those decisions may impact the prices on market, returns and the resources allocation. The theory has its roots in the eighteenth century with significant works like Moral Sentiment theory (1759) and Nations Wealth theory by Adam Smith. Smith suggested that there is presence of an "invisible hand", forces or individual morality that guides them while they are making social, economic and even financial decisions. Sewell (2007) reported that the behavioural finance studied the influence of psychology on the behaviour of people involved in all financial sector and the effect on market that encounter from it.

Behavioural finance had an important role in capital markets through helping in financial decisionmaking process. All possible alternatives in decision making are evaluated for proper and better investment (Mathews, 2005). Its paradigm suggests that the decision for investment is associated with emotional and psychological factors such as envy, fear, euphoria, feelings, panic, anxiety, greed, ambition, satisfaction, or vanity. It is likely that these emotional factors can interfere with individual decision making in financial investment (Birau, 2011).

Behavioural finance may have a connection with complex situations of financial market. It helps to find mispricing, irrational decision making in investing and profit anomalies. Empirical studies have shown that investors used the overconfidence in their judgements and sometimes mistakes in decision making may occur. The overreaction of investors in certain circumstances may have also some negative effects in decision making.

\section{Materials and Methods}

The descriptive research design was used. The quantitative method was used, and correlation of inferential statistic was used to find out the relationship between the independent and dependent variables. For that, the frequencies were used to present, interpret the findings. The random sampling technique was used to determine a sample size. The structured questionnaire was used to collect the findings. A statistical package social sciences (SPSS) software version 20 was used in data analysis procedure. Descriptive methods helped a researcher for making conclusion of results and research used $90 \%$ as confidence level.

The target population is the study object that may be taken as group, organization or individual depending on the research objectives. This research, the target population was 1282 staff of Bank of Kigali, Rwanda.

The sampling techniques was been used the strata because the employees founded in different department or division of staff. The sample was been obtained after considering the list of all staff member 
from target population with their respective branches located in Kigali city. After having in hand, the list of staff, the Slovin's formula was been used to determine the sample size from target population.

Table 3.1: Sample size determination

\begin{tabular}{lccc}
\hline Institution & Number of branches & Target population & Sample size \\
\hline BK & 68 & 1282 & 92 \\
\hline
\end{tabular}

The structured questionnaire was used to collect the data, the questionnaire comprised with the questions related to the specific objectives of the study, and the researcher used the data for obtaining the information related to these objectives. The respondents by answering through close-ended questions, they provided the exact information and from them the researcher formulated the opinions and conclusions.

The results were analysed by using the IBM statistical package for social sciences (SPSS version 20) software. The tables were used to interpret the results centred on the analysis of the distribution of the percentages. The data were analysed through frequencies.

\section{Results and Discussion}

4.1 Demographic Characteristics of Respondents This subsection focuses on marital status, gender, ages and education of respondents and their partners.

\subsubsection{Gender of Respondents}

Researcher concerned on the gender distribution of respondents for getting a picture of gender and to find out whether the independent variables on dependent variables depend on a personnel gender status. The findings were presented in the table 4.1.

\section{Table 4. 1: Gender}

\begin{tabular}{rrcccc}
\hline & & Frequency & Percent & Valid Percent & Cumulative Percent \\
\hline \multirow{3}{*}{ Valid } & Man & 40 & 43.5 & 43.5 & 43.5 \\
& Woman & 52 & 56.5 & 56.5 & 100.0 \\
& Total & 92 & 100.0 & 100.0 & \\
\hline
\end{tabular}

Source: Primary data, (2021)

Out of 92 respondents, 40 respondents were men covers a $43.5 \%$ while 52 respondents were women covers $56.5 \%$ of all. This means that among the target population and all staff female is more than male. This could be to the fact that women are very interested in socio-economic studies. The majority of women like to attend their studies in non-exact science, therefore a highest number of women in banking sector. In addition, this could be to the fact that women are very welcome in banking because of their best customer care.

\subsubsection{Age Group of Respondents}

The results on the age of respondents are presented in table 4.2.

Table 4. 2: Range of years

\begin{tabular}{llcccc}
\hline & Frequency & Percent & Valid Percent & Cumulative Percent \\
\hline \multirow{4}{*}{ Valid } & Below 30 & 10 & 10.9 & 10.9 & 10.9 \\
& 31-40 years & 37 & 40.2 & 40.2 & 51.1 \\
& 41-50 years & 41 & 44.6 & 44.6 & 95.7 \\
& Above 50 years & 4 & 4.3 & 4.3 & 100.0 \\
& Total & 92 & 100.0 & 100.0 & \\
\hline
\end{tabular}

Source: Primary data. (2021)

Out of 92 respondents, 10 respondents $(10.9 \%)$ had bellow 30 years, 37 respondents $(40.2 \%)$ had between 31-40 years, and 41 respondents (44.6\%) had between 41-50 years while 4 respondents $(4.3 \%)$ had above 50 years. Hence, by taking into consideration of different age the researcher realized that the contacted respondents were of reasonable age and in position to give careful and well analyzed information that could facilitate making of necessary and relevant conclusions. The results showed that more than $80 \%$ of respondents were in the age of 31 50 , a working age in the office especially banking 
sector for more employees in Africa. The lowest number of employees with more than 50 in age could be to the fact that the banking sector needs the energetic staff who can even conduct their job and attributions in the difficult time especially the extra hours, and in the weekends.

\subsubsection{Education of Respondents}

The education level of respondents was taken as important information that may affect the independent variables on the dependent variables. The findings were presented in the table 4.3.

\section{Table 4. 3: Education of respondents}

\begin{tabular}{|c|c|c|c|c|c|c|}
\hline & & & Frequency & Percent & Valid Percent & Cumulative Percent \\
\hline \multirow{4}{*}{ Valid } & Bachelors & & 55 & 59.8 & 59.8 & 59.8 \\
\hline & Masters & & 35 & 38.0 & 38.0 & 97.8 \\
\hline & $\begin{array}{l}\text { Others (professional } \\
\text { ACCA and CPA) }\end{array}$ & courses, & 2 & 2.2 & 2.2 & 100.0 \\
\hline & Total & & 92 & 100.0 & 100.0 & \\
\hline
\end{tabular}

Source: Primary data, (2021)

Out of 92 respondents, 55 respondents (59.8\%) had Bachelors, and 35 respondents $(38 \%)$ had Masters while 2 respondents $(2.2 \%)$ in addition of bachelors or masters had also other professional courses, ACCA and CPA. The high level of education of respondents shows that respondents are easy to understand the questionnaire and guarantee the reliability of the answers. The education level of respondents in banking sector is attributed to the fact that the sector is a specialized one and obliged their staff to have at least a bachelor degree in order to work in their institution. This is also associated to the improvement of education sector in Rwanda, since 1994 post genocide against Tutsi. More universities were created and the access to them was easier. In addition, more universities with banking, accounting, and management departments were very prevailing. This may be to the fact that department does not need sophisticated or specialized materials or equipment.
4.2 Findings of objective:Effect of behavioural finance of investor's participation on investments in capital markets

Behavioral finance is the study of the influence of the psychological factors on financial markets evolution. It suggests that investment decision is influenced in a large proportion by psychological and emotion all factors. Decision making with behavioral finance, can be defined as the process of choosing a particular investment alternative from a number of alternatives. A very important step for an investor is to understand his financial personality.

\subsubsection{The statements that best describe the thinking about how behavior finance factors influence the investors to participate on capital markets}

The researcher wanted to know how the statements described by respondents on thinking about finance factors influence the investors to participate on capital markets. The findings were presented in the table 4.4.

Table 4. 4: Views of respondents on awareness of investing in capital market

\begin{tabular}{llcccc}
\hline & Frequency & Percent & Valid Percent & Cumulative Percent \\
\hline \multirow{4}{*}{ Valid } & Strongly agree & 20 & 21.7 & 21.7 & 21.7 \\
& Agree & 28 & 30.4 & 30.4 & 52.2 \\
& Undecided & 38 & 41.3 & 41.3 & 93.5 \\
& Disagree & 4 & 4.3 & 4.3 & 100.0 \\
& Strongly disagree & 2 & 2.2 & 2.2 & \\
& Total & 92 & 100.0 & 100.0 & \\
\hline
\end{tabular}

Source: Primary data (2021)

Out of 92 respondents, $21.7 \%$ strongly agreed, $30.4 \%$ agreed, $41.3 \%$ were undecided, $4.3 \%$ disagreed and $2.2 \%$ strongly disagreed. The term investor awareness has been used in investor communities' frequently. It describes the investor literacy or knowledge about the investment environment or about the investment environment or about the industry as a whole. It is significant since investors are expected to make their investment decisions based on the information and knowledge. Investor awareness is the knowledge of investment and about the important updates of the market. Investor awareness is crucial for the investment decision making and sustainable growth of capital market. The results showed that many respondents $(52.1 \%)$ have an awareness of investing in capital market. They may know the benefits from it. As 
bank staff, they know already the interest and the future trend of capital market in Rwanda.

Table 4. 5: Views of respondents on availability of funds for investors

\begin{tabular}{llcccc}
\hline & Frequency & Percent & Valid Percent & Cumulative Percent \\
\hline \multirow{6}{*}{ Valid } & Strongly agree & 68 & 73.9 & 73.9 & 73.9 \\
& Agree & 18 & 19.6 & 19.6 & 93.5 \\
& Undecided & 5 & 5.4 & 5.4 & 98.9 \\
& Disagree & 1 & 1.1 & 1.1 & 100.0 \\
& Total & 92 & 100.0 & 100.0 & \\
\hline
\end{tabular}

Source: Primary data, (2021)

Table 4.5 indicates perception of respondents on views of respondents on availability of funds for investors to invest in capital market. Out of 92 respondents, $73.9 \%$ strongly agreed, $19.6 \%$ agreed, $5.4 \%$ were undecided while $1.1 \%$ disagreed. Investor's trust in investing in capital market gives a positive impact for their fund's maximization.

Table 4. 6: Views of respondents on how cost of share can motivate you to invest in capital market

\begin{tabular}{llcccc}
\hline & Frequency & Percent & Valid Percent & Cumulative Percent \\
\hline \multirow{6}{*}{ Valid } & Strongly agree & 28 & 30.4 & 30.4 & 30.4 \\
& Agree & 34 & 37.0 & 37.0 & 67.4 \\
& Undecided & 24 & 26.1 & 26.1 & 93.5 \\
& Disagree & 5 & 5.4 & 5.4 & 98.9 \\
& Strongly disagree & 1 & 1.1 & 1.1 & 100.0 \\
& Total & 92 & 100.0 & 100.0 & \\
\hline
\end{tabular}

Actually there are investors who are deciding not to personal reasons. The highest number of agreed respondents $(92.5 \%)$ infringed that people know the benefits of investing in capital market and the returns that may gain from it. invest their funds in the capital market because of

Source: Primary data, (2021)

Table 4.6 indicates views of respondents on how cost of share can motive you to invest in capital market. Out of 92 respondents, $30.4 \%$ strongly agreed, $37.0 \%$ agreed, $26.1 \%$ were undecided, $5.4 \%$ disagreed while $1.1 \%$ were strongly disagree. In general, $67.4 \%$ agreed that the share can motivate the investment in capital market. According to the efficient market hypothesis, investments decisions should be made neither on the basis of observed sequences of returns, nor even extreme historical values. Investors might be interested to compare the current price to its historical peaks and the media simply try to satisfy their curiosity.

Table 4. 7: Views of respondents on how return can motivate you to invest in capital market

\begin{tabular}{|c|c|c|c|c|c|}
\hline & & Frequency & Percent & Valid Percent & Cumulative Percent \\
\hline \multirow{4}{*}{ Valid } & Strongly agree & 29 & 31.5 & 31.5 & 31.5 \\
\hline & Agree & 60 & 65.2 & 65.2 & 96.7 \\
\hline & Undecided & 3 & 3.3 & 3.3 & 100.0 \\
\hline & Total & 92 & 100.0 & 100.0 & \\
\hline
\end{tabular}

Source: Primary data, (2021)

Table 4.7 shows on how return can motivate you to invest in capital market. Out of 92 respondents, $31.5 \%$ strongly agreed, $65.2 \%$ agreed and $3.3 \%$ were undecided in terms of how return can motivate the investors in capital market. Generally, $96.7 \%$ are attracted by the returns gained from capital market.
So they are more interested. A good investment is one that generates returns which are as high as possible given the level of attached risk. The relationship between return expectations and market return holds self-directed individual investors. 
Table 4.8 Correlation analysis

\begin{tabular}{|c|c|c|c|c|c|c|}
\hline & & Knowledge Level & $\begin{array}{l}\text { Behaviors } \\
\text { Finance }\end{array}$ & $\begin{array}{c}\text { Dividend } \\
\text { Growth }\end{array}$ & $\begin{array}{c}\text { Investments } \\
\text { Decisions }\end{array}$ & $\begin{array}{c}\text { Return on } \\
\text { Investments }\end{array}$ \\
\hline & Pearson Correlation & 1 & $.820^{* *}$ & $.856^{* *}$ & $.712^{* * *}$ & $.919^{* * 3}$ \\
\hline \multirow[t]{3}{*}{ Knowledge Level } & Sig. (2-tailed) & & .000 & .000 & .000 & .000 \\
\hline & $\mathrm{N}$ & 92 & 92 & 92 & 92 & 92 \\
\hline & Pearson Correlation & $.820^{* *}$ & 1 & $.853^{* *}$ & $.632^{* *}$ & $.879^{* *}$ \\
\hline \multirow[t]{3}{*}{ Behaviors Finance } & Sig. (2-tailed) & .000 & & .000 & .000 & .000 \\
\hline & $\mathrm{N}$ & 92 & 92 & 92 & 92 & 92 \\
\hline & Pearson Correlation & $.856^{* *}$ & $.853^{* *}$ & 1 & $.579^{* * *}$ & $.803^{* *}$ \\
\hline \multirow[t]{3}{*}{ Dividend Growth } & Sig. (2-tailed) & .000 & .000 & & .000 & .000 \\
\hline & $\mathrm{N}$ & 92 & 92 & 92 & 92 & 92 \\
\hline & Pearson Correlation & $.712^{* *}$ & $.632^{* *}$ & $.579^{* *}$ & 1 & $.715^{* *}$ \\
\hline \multirow[t]{3}{*}{ Investments Decisions } & Sig. (2-tailed) & .000 & .000 & .000 & & .000 \\
\hline & $\mathrm{N}$ & 92 & 92 & 92 & 92 & 92 \\
\hline & Pearson Correlation & $.919^{* *}$ & $.879^{* *}$ & $.803^{* *}$ & $.715^{* *}$ & \\
\hline \multirow[t]{2}{*}{ Return on Investments } & Sig. (2-tailed) & .000 & .000 & .000 & .000 & \\
\hline & $\mathrm{N}$ & 92 & 92 & 92 & 92 & 92 \\
\hline
\end{tabular}

**. Correlation is significant at the 0.01 level (2-tailed).

Source: Primary data, (2021)

Table 4.8 shows the correlation between the knowledge level of investments and behavior finance; dividend growth; investments decision and return on investment. Where knowledge level of investments are positively correlated with behavior finance with correlation coefficient of 0.82 (82\%), this leads to confirm that there is significant relationship between knowledge level of investments and behavior finance; knowledge level of investments are positively correlated with dividend growth with correlation coefficient of 0.856 (85.6\%); knowledge level of investments are positively correlated with investments decision of 0.712 (71.2\%); knowledge level are positively correlated

Table 4.9 Model summary with return on investment of 0.919 (91.9\%); behavior finance is positively correlated with dividend growth of $0.853(85.3 \%)$; behavior finance is positively correlated with investments decision of 0.632 $(63.2 \%)$; behavior finance is positively correlated with return on investment of 0.879 (87.9\%); dividend growth is positively correlated with investments decision of 0.579 (57.9\%); dividend growth is positively correlated with return on investment of $0.80 .3(80.3 \%)$ and investments decision is positively correlated with return on investment of 0.715 $(71.5 \%)$. Therefore, this study found that there is a significant relationship between all independent variables dividend returns and dependent variables of investments for the staff of Bank of Kigali.

\begin{tabular}{lcccc}
\hline Model & $\mathrm{R}$ & $\mathrm{R}$ Square & Adjusted R Square & Std. Error of the Estimate \\
\hline 1 & $.727^{\mathrm{a}}$ & .529 & .513 & .348 \\
\hline
\end{tabular}

a. Predictors: (Constant), Dividend Growth, Behaviors Finance, Knowledge Level

Source: Primary data, (2021)

$\mathrm{T}$

able 4.9 presents the model summary test, it indicated that the variables were statistically significant with R Square was 0.529 and $\mathrm{R}$ of $0.727(72.7 \%)$.

Table 4.10ANOVA ${ }^{\mathrm{a}}$

\begin{tabular}{llccccc}
\hline Model & & Sum of Squares & df & Mean Square & F & Sig. \\
\hline \multirow{3}{*}{1} & Regression & 11.959 & 3 & 3.986 & 32.939 & $.000^{\mathrm{b}}$ \\
& Residual & 10.650 & 88 & .121 & & \\
& Total & 22.609 & 91 & & & \\
\hline
\end{tabular}

a. Dependent Variable: Investments Decisions

b. Predictors: (Constant), Dividend Growth, Behaviors Finance, Knowledge Level

Source: Primary data, (2021) 
Table 4.10 presents the anova test, it was clear that the variables were statistically significant with $\mathrm{F}=32.939, \mathrm{~F}=0.000$, it was clear that variable of return on investment can be explained by one's of the all variables of independent.

Table 4.11Coefficients ${ }^{\mathrm{a}}$

\begin{tabular}{llccccc}
\hline Model & & \multicolumn{2}{c}{ Unstandardized Coefficients } & $\begin{array}{c}\text { Standardized } \\
\text { Coefficients }\end{array}$ & t & Sig. \\
\hline & & B & Std. Error & Beta & & \\
\hline & & .500 & .123 & & 4.051 & .000 \\
1 & (Constant) & .510 & .106 & .721 & 4.806 & .000 \\
& Knowledge Level & .257 & .140 & .273 & 1.832 & .070 \\
& Behaviors Finance & -.202 & .123 & -.271 & -1.644 & .104 \\
\hline
\end{tabular}

a. Dependent Variable: Investments Decisions

Source: Primary data

Table 4.11 presents the coefficients test on investment decision, it was clear that the variable were statistically significant with standardized coefficients $($ Beta $)=0.721, \mathrm{p}=0.000$ on knowledge level, $0.273, \mathrm{p}=0.070$ on behaviors finance and low standardized coefficients (Beta) $-0.271, \mathrm{p}=0.104$ on dividend growth, it was clear that the variables of knowledge level and behavior finance were positively significant and one of dividend growth was negatively significant correlated.

\section{Conclusion}

This research concluded that financial literacy has the impact on investments in capital marketof bank of Kigali staff. This research concluded that the staffs of Bank of Kigali are interested in 3 types of products shares, Unit Investment Trust and bonds. Therefore, more staffs were entering in capital market via institution (Bank of Kigali).

This study also concluded that there is a strong effect of behaviour finance of investor's participation on investments in capital markets. It is also concluded that there is a strong impact of availability of funds for investors to invest in capital market. This study also concluded that, cost of share, the amount of return and easiness of selling capital products motivate the respondents to invest in capital market. The respondents are risk averse of investing in capital market. This research concluded that the respondents have Confidence of investing in capital market. The analysis showed that, investments are positively correlated to dividend returns with correlation coefficient of 0.715 . This leads to confirm that there is significant correlation between investments and dividend returns. The study also concluded that there is a relationship between dividend growth and investments in capital market of bank of Kigali staff. This research concluded there is an important of the dividend return and its impact on capital market in Rwanda. This study concluded that there is a significant relationship between all independent variables dividend returns and dependent variables of investments for the staff of Bank of Kigali.

\section{Acknowledgments}

First and foremost, I would like to thank our Almighty God for his invaluable assistance upon my steps. The success of this research could not be achieved without the guidance and moral support of Mount Kenya University (MKU) Management and staff. I would equally important like to extend my special thanks to my supervisor Dr Rusibana Claude for his encouragement and advice throughout the process. I would like also to express my deepest gratitude to my brothers for being by my side during my studies and research journey. I cannot forget to acknowledge the massive contribution from my classmates for making my study life enjoyable and conducive at MKU. You have truly been a blessing to me. I will always be grateful to you all forever.

\section{References}

[1] Aregbeyen, O., \&Mbadiugha, S. O. (2011). Factors influencing investors decisions in shares of quoted companies in Nigeria. The Social Sciences, 6(3), 205-212.

[2] Birău, F. R. (2011). Behavioral finance paradigm and its implications on investment decisions. InInternational Scientific Conference ,ECO-TREND (pp. 25-26).

[3] Cassimon, D., Essers, D., \&Verbeke, K. (2016). The changing face of Rwanda's public debt. German Development Institute, 1-23

[4] Fares, A. R. F., \&Khamis, F. G. (2011). Individual investors' stock trading behavior 
at Amman Stock Exchange. International Journal of Economics and Finance, 3(6), 128-134.

[5] Gervais, S., Heaton, J. B., \&Odean, T. (2002). The positive role of overconfidence and optimism in investment policy.

[6] Gill, S., Khurshid, M. K., Mahmood, S., \& Ali, A. (2018). Factors effecting investment decision making behavior: the mediating role of information searches. European Online Journal of Natural and Social Sciences, 7(4), pp-758.

[7] Hussain, M. F., \&Nasrin, S. (2012). Factors affecting selection of equity shares: the case of retail investors in Bangladesh. European Journal of Business and Management, 4(20), 110-124.

[8] Jain, D., \&Mandot, N. (2012). Impact of demographic factors on investment decision of investors in Rajasthan. Researchers World, 3(2), 81.

[9] Kabra, G., Mishra, P. K., \& Dash, M. K. (2010). Factors influencing investment decision of generations in India: an econometric study.

[10] Lindawati, A. S. L., \&Roselin, T. (2013). The risk phenomenon of investing in capital market (individual broker perception). Journal of Economics, Business, \& Accountancy Ventura, 16(2), 237-250.

[11] Mahina, J. N., Muturi, W. M., \&Memba, F. S. (2014). Effect of behavioural biases on investments at the Rwanda Stock Exchange. International journal of social sciences and information technology, 3(3), 1917-1933.

[12] Masomi, S. R., \&Ghayekhloo, S. (2011). Consequences of human behaviors' in economic: the effects of behavioral factors in investment decision making at Tehran stock exchange. In international conference on business and economics research (Vol. 1, No. 2011, pp. 234-237).

[13] Mathews, J. (2005). A situation-based decision-making process. The ICFAI Journal of Organisation Behaviour, July, 4(3), 19-25.

[14]MINECOFIN (2019), Annual economic report fiscal year 2017/2018.

[15] Ngahu, A. N. (2017). Factors Influencing Investment Decisions in Equity Stock among Retail Investors in Kenya (Doctoral dissertation, KCA University).

[16]Ryan, R. M., \& Deci, E. L. (2000). Intrinsic and extrinsic motivations: Classic definitions and new directions. Contemporary educational psychology, 25(1), 54-67.

[17] Tapia, W., \&Yermo, J. (2007). Implications of behavioural economics for mandatory individual account pension systems.

[18] Vansteenkiste, M., Niemiec, C. P., \&Soenens, B. (2010). The development of the five mini-theories of self-determination theory: An historical overview, emerging trends, and future directions. In the decade ahead: Theoretical perspectives on motivation and achievement 